\title{
Sapir Whorf Hypothesis and its Relevance to the Language Expression “Bombongan" in Ethnic Java of Panaragan
}

\author{
Alip Sugianto ${ }^{1}$, Wakit Abdullah ${ }^{2}$, Sumarlam $^{3}$, Sahid T Widodo ${ }^{4}$ \\ Sebelas Maret University, Surakarta, Indonesia ${ }^{1-4}$ \\ \{alipsugianto@student.uns.ac.id ${ }^{1}$, sumarlamwd@gmail.com ${ }^{3}$, \\ sahidteguhwidodo@yahoo.com $\left.{ }^{4}\right\}$
}

\begin{abstract}
Ponorogo as one of the ethnic in East Java has a uniqueness that is not owned by other regions. The uniqueness is located in the language "Bombongan" contained in Ponorogoreyog community. The language is usually used by the reyog community or warok with a specific purpose. In this article examine Sapir Whorf's hypothesis against the language of Bombongan ethnic Panaragan, where between Language, Mindset and culture are closely related in a society. For example, the word Jegeg is the result of the mindset of the public associated with the behavior of warok over his prowess in the form of cultural practices in the art of reyog. In the language, it is the result of the actualized mindset into language and culture, so that the three relationships are closely related.
\end{abstract}

Keywords: Sapir Whorf Hypothesis and Bombagan Language, Ethnic Panaragan

\section{Introduction}

"Akah akehe wong Ponorogo omongekaku, srogal-srogol, kandhaapaanane. Ora duwepariasikandhalelamisan. Tata lahirekasar, nangingsatemeneatinemuluslantulus".So the opinion of the author of Babad Ponorogo about the language used by the people of Ponorogo in general[1]. Borrowing the terms Williem Von Humboldt, a German philosopher, says that "the language is the representation or embodiment of the natural spirit and national character of society"[2]. Furthermore, Humboldt believes that every language in the world must be a manifestation of the culture of its speaker community. Thus, the view held by a particular language society will be reflected or manifested in its language.

Thus, language is regarded interconnected with culture, or it can be said that the language used by the people of Ponorogo is a reflection of the mindset of the culture. Speaking of Culture Ponorogo cannot be separated from the tradition of kanoragan which must be taken by a warok to obtain kesakten with salacious behavior nglakoni or tirakat. A warok must control the so-called "rehkamusakansejati" (true human path) in the behavior, then a warok will be a superior person "tan tandhas tread hammer pandesisanegerindhatinumbak distorted jinara muter"Kondang kedigdayan, saktimandraguna not work all weapons .

Life and reality in the reyog art that is famous for life 'hard' makes a warok must be able to conquer his 'hard' life with the courage to be a knight. Warok tradition finds its roots in rebellion mythology. According to many literatures, the warok tradition begins with the character of $\mathrm{Ki}$ Ageng Kutu Suryongalam, a wengker ruler who strongly opposes King 
Brawijaya V King of Majapahit because of the political influence of his wife from Chinese descent so that his political policy does not benefit the community. Ki Ageng Kutu, then set up a peguron a place that teaches the science of kebatinan, immunity and perfection to the synagogues in the hope that this will form a strong base for a Majapahit awakening.

The tradition of warok continues in the following decades. In the reign of the Dutch East Indies warok known as a troublemaker and made a threat to the Dutch colonial position in Ponorogo so the Dutch government banned reyog show until 1912-1932. As expressed by Dutch officials "reyog attracts a large number of people who seek supernatural powers that present a threat to security"[3].One of the boldness of warok Ponorogo is shown by warok Mertopuro; he valiantly killed the Dutch Resident in Ponorogo William Vincent in his office because of his policy of Stesel Culture 'forced cultivation of coffee' which makes the people of Ponorogo much harmed because it must be sold cheaply to the Dutch Colonial government.

The hard life of the people of Ponorogo flowing brave souls in the children and grandchildren of the people of Ponorogo, hence the language used by most people of Ponorogo is famous without the tedengaling-aling, branggasan, and rough impressed. Usually, such use used to "brag" to the younger generation in order to have courage. For that reason, this simple writing would like to examine the Javanese Ethnic Javanese Language which emphasizes the phrase "bombongan" that can reflect the culture. Or in other words, The language used by the Javanese Ethnic Panaragan community can reveal the feelings of the mind, as well as the desire by the people who use the language in particular interest in the Sapir Whorf Hypothesis Review.

\section{Result and discussion}

\subsection{Sapir Whorf Hypothesis}

Speaking of language, mindset, and culture is not separated with the thoughts of Edward Sapir and Benjamin Lee Whorf, Integrated teacher and student is known as Sapir Whorf Hypothesis. The hypothesis has two well-known perspectives: Linguistic Determinism which states that Languages see that language structures control the mind and cultural norms[4]. In other words, human beings are simply living in a small part of the world where possible the language they use. So the world we know is primarily determined by the language taught by our culture. Thus language differences present also the basic differences in the world view of different cultures. Another view is called Linguistic Relativity that language assumes that language characteristics and cultural norms interact. With other meanings, culture is controlled and simultaneously controls the language. Based on this interpretation the language provides conceptual categories that affect how perceptions of its use are coded and stored.

Edward Sapir (1884 - 1939) the American linguist has the same opinion as Von Humboldt. Sapir says that humans live in this world under the "compassion" of their language which has become a medium of introduction in their social life. According to Sapir, it has become the fact that a society is partly "erected" above the characters and attributes of the language. Therefore, no two languages are the same so they can be considered to represent the same community [5]. Firmly Sapir also says what we see, we hear, we experience, and we do now is because the qualities of our language have outlined it first[4].

Benjamin Lee Whorf (1897 - 1941), Sapir's disciple, rejects the classical view of language relations and thinking that language and thinking are two independent things. The classical view also says that although every language has different sounds, they all state the same 
formulas based on the same thoughts and observations. Thus all these languages are ways of parallel and mutually interpretable thought of each other[4]

Similar to Von Humboldt and Sapir, Whorf also states that language determines one's mind until it can sometimes endanger itself. For example, Whorf who was a former firefighter declared an "empty can" of oil scraping. The word blank is used in the sense that there is no oil in it. When in fact there is enough effect-off (after effect) on oil cans to explode. If the contents of the cans are thrown away, the tin will be empty, but in chemistry, this is not always true. Empty oil cans can still explode when exposed to heat. Here, according to Whorf, it appears that one's mind has been determined in the language.

According to Whorf then the grammar system of a language is not only a tool for expressing ideas, but also forming those ideas, is a program of one's mental activity, the determinant of one's mental structure. In other words, it is the grammar that determines one's thinking, not words. The Sapir-Whorf hypothesis seems to focus more on the relationship between grammar and the human mind, not words

In his research of the Hopi language, one of the Indian languages in the California United States profoundly, Whorf proposed a hypothesis called the Whorf hypothesis or also called Sapir Whorf's hypothesis of linguistic relativity. According to the hypothesis, different languages "dissect" nature in different ways, thus creating the relativity of conceptual systems dependent upon the diverse languages used by various community groups

The hypothesis of linguistic relativity assumes that language is only a reflection of the thought that gives rise to meaning. Language influences the mind, so the expression that language influences the speaker's way of thinking. Linguistic determinism is the claim that language determines or greatly affects the way one thinks or perceives the world. Whorf was deeply impressed by the fact that each language emphasizes the difference in structure based on different aspects of the world as the foundation for the formation of that structure. $\mathrm{He}$ believes that the emphasis has had a considerable impact on the way speakers speak of the world. Whorf believes that the life of a society is built by the language traits that members of that society use[6].

The influence of language on the mind can occur through habituation and the formal aspects of language, such as grammar and lexicon. Whorf says "Grammar and lexical resources of individual languages heavily constrain the conceptual representations available to their speakers" (Grammar and lexicon in a language become the determinant of the conceptual representation that exists in the language user). In addition to the habituation and formal aspects of language, one of the dominant aspects of the Sapir and Whorf concept is that language problem affect categorization in human perception that will be the premise of thinking.

To support the Hypothesis, Sapir and Whorf explain some examples. One of them is the word snow. Whorf said that most humans have the same word to describe melting snow, all snow objects are still called snow. In contrast to most of the Eskimotribe, people give diverse lobes to the snow. Even in Indonesia as it is to call the term banana has a variety of bananas, ulin bananas, pisokkepok, banana ambon and so forth. But in English society, know banana with the term banana. Whorf feels that such a diverse term, causing the language speakers to perceive the world differently from a person who has only one word for a particular category. Sapir rejects the view that thinking and speaking two distinct entities stand on their own. Sapir and Whorf agree that language determines one's mind. The way a person's mind is determined by his language.

Based on the Sapir-Whorf hypothesis, it can be said that the life and outlook of life of the nation with each other has a different structure. For example, a nation in Southeast Asia with 
America, Africa or Europe. To emphasize this, Whorf compares the Hopi culture and European culture. Hopi culture is organized based on events, while European culture is organized by space and time. According to the Hopi culture if one seed is planted, then the seed will grow. The time required between planting and growing seeds is not important. What is important is the planting event and the growth of the seeds. As for Europeanculture, the time period is what matters. According to Whorf, this is evidence that their language has defined the reality of life in different ways.

To show that language leads the way of the human mind, Whorf shows another example. The sentence sees that wave in English has the same pattern as the sentence see that house. In see that house we can indeed see a house, but in the sentence see that wave according to Whorf no one has seen one wave. So, here we seem to see a wave because the language has described it to us. this is a factual falsehood presented by one such living organization; and we are not aware that our worldview has been confined by actual unlawful bonds

The language for Whorf is the guide of social reality. Although language is usually not sought by social scientists, language strongly conditioned the individual's mind about a social problem and process. Individuals do not live in an objective world, not only in the world of social activity as they are commonly understood, but it is determined by a certain language that becomes the medium of declaration for the people. No two languages are sufficiently equal to represent the same reality. The world where various communities live is rated by Whorf as the same world but with different characteristics. In short, it can be concluded that the human view of the world is shaped by language so that because language is different then the worldview is different. Selectively individuals filter incoming sensory as programmed by the language it uses. That way, people who use different languages have different sensory[7].

Based on the description above, it can be concluded that language and mind cannotbe separated from each other. Both are closely related because what determines one's mind is grammatical rather than words. Therefore, language has a role not only limited to media mechanisms communicating with one another but also as a guide to a direction of social reality. It can be proven when someone speaks differently because they are different ways of thinking.

\subsection{The "Bombong" Language of the Panaragan Javanese Ethnic Society}

The cultural condition of the Panaragan community is thick with magical mystical aura, where the people have a culture that requires a linuwih force in the supernatural field. So it is not surprising that the Panaragan ethnic figure, in this case,warok, must perform the ritual behavior to obtain a supernatural power. Such strength is used in various entrapments that have the properties of the marang liyan. His role in the art of reyog, a warok is a central figure as an elder who served as a protector in the stage of the various possibilities that occur either visible or not.

So a warok abstinence to retreat if you get a "gimme or challenge" be it riot-as well as subtly visible. This brave nature indirectly shapes the character of the Panaragan community by having high self-esteem. Therefore often in the practice of life in society there are many expressions conveyed by the warok to motivate for the younger generation to be brave because the truth that must be fought until the end of the blood or the term people Ponorogocall the character people of Ponorogo with proverb 'Yen Lemes Keno Kangge Ropes, Yen Kaku Keno Kagge Pikulan, Gelem Ngalah, Nangin Yen Ora Keno Dikalahi Malih Ndadi Mangsun Bebayani 
This condition makes the culture of the people of Ponorogo inevitably flowing brave blood inherited from the famous ancestor has many powers, if having fear sometimes requires injection with the language "bombongan" this language is essentially often used in conversations on the reyog community. Because in this art, it requires extra strength that is rested on the jaw and teeth in lifting dad peacocks that weigh more than $50 \mathrm{~kg}$. A person who does not have the power will be afraid, shrinking and not bearing the weight so heavy. Even so, it is also supportedatmosphere traditional sounds that area song by wirosworo or senggakanthat brings rhythm motivation to have a brave soul.

The strains wirosworo buzzing usually follow the storyline in reyog art that is inspired by two versions of Bantarangin and Wengker stories[8][9]. Both versions tell about war so that the tones in the art of reyog inspire spirit knight people of Ponorogo. The typical tone in the reyog show is Ha'e, Hok'ya, Hae, Hae ya. Strains are often motivated soul spirit of the warok with the language of "bombongan" or flattery with phrases like the following:

- Ikilodlondonge wong Ponorogo the intent of the phrase is 'this is the grandson of people Ponorogo' as a grandson of Ponorogo people will feel ashamed if it does not have brave and knight nature. That character must be shown in every virtue, Ponorogo people do not claim to be Ponorogopeople if they still have fear in doing good.

- Jian ora dlomoklur the phrase has the equivalent of the word in Indonesian 'It is not common brother' Usually this expression is spoken when looking at something beyond the limits of reasonableness. Such miracles warok Ponorogo beyond the limits of the reasonableness of society in general, causing the effect of admiration on others.

- Ponorogo Jegeg this phrase popularized by Regent Amin every time to get the achievement and appreciation,so he gave appreciation with the phrase Ponorogo Jegeg, this phrase finally became a community custom and became a development Jargon, Regent Amin. The meaning of the word Jegeg has the equivalent of good, top or sip. This expression as a form of appreciation Ponorogo people to the good done by someone so that to improve the goodness of the need for motivation with the word Jegeg.

- Regeng Gayengis usually followed by communal followers' sentences in a paguyuban or group. For example Come collect ben regenggayeng, ora congkrahagawebubrah who have the intention of let us get together so familiar, not exchange that makes the fight. Because the reyog community requires a lot of personnel with different backgrounds and characters, it is often necessary to get together to match the vision and mission perceptions, and exchange ideas from each member to have the same aura. So that there will be no dispute that makes the conditions become damaged. So, if there is someone who is less active in reyog exercises then often hear an invitation to join with the sentence ayo lurkumpul ben regenggayeng.

- Teyenghas the equivalent of ora iso. In language usage is often understood by owners and users of the language. So sometimes the meaning of speech is known in the context of the language. For example 'Bocahkui sekteyeng' which means that the child can not yet. The purpose of the sentence, used as a mockery with the intention of giving motivation to the opponent said to try maximally to get what he wants.

- Kesi has the lexical meaning of kesi is able or can do something. Usually used to combine someone when in doing an activity. For example, loneliness ki. This expression is then usually responded with no kes. In the Java language is generally kesi this same with pecus or becus.

- Kaloko has a well-known cultural significance. Usually, a warok that has kalokokesaktiannya have many students. Jian kalokotenanwarok Singojoyo ora tedas in 
bacok. Expression of kaloko expression is used as a form of admiration of a person with a form of praise.

- Gitapan meaning is diligent. This expression as a form of 'bombongan' for someone to be diligent. Or also can be as a form of appreciation bocahkuigitapan or child is really diligent

- Jadog has the meaning of a bold word, this word is usually pronounced with the sentence dadi wong kudu jadog. It means being brave. Do not be coward. Brave here has a meaning in the form of positive deeds.

- CukatTanndang has a nimble meaning or ready to respond because in the use of word jadog used in doactical cultural sphere that requires preparedness, then koncoreyog another term for bolo reyog should be deft because this art requires agility.

- Gumregah has a happy meaning the word is used to express a happy atmosphere. The boys sing delokreyogpodogumregah. 'Kids who see reyogs on happy'

From the various examples of the phrase "bombongan" in the Javanese Panaragan ethnic, it shows that the language used has a close connection with the hard Panaragan culture so that the culture affects the way the language seems rough. In essence culturally, the Panaragan language is so, as Poerwowijoyo thinks with the phrase srogal-srogol. Over the course of time, Panaragan dialect languages have shifted from Javanese Mataraman

The influence of the culture of Mataraman entered into Panaragan culture during Paku Buwono II era when there was a peccine in the palace Kartosuro. Paku Buwono II fled to Ponorogo asking for the help of warok Ponorogo in overcoming polemic uprising conducted by Raden Mas Garendi, at the time in Ponorogo, studied at a charismatic kiai named Kiai Ageng Muhammad Besari from Boarding School of Tegalsari. While in Ponorogo he also collects the warok with the coordinator by the warok Ponorogo, who is highly respected by the community, namely Surobroto who is a Ponorogo regent from that relationship. Paku Buwono II received heirloom from the regent in the form of kyaislamet and kebobule. The relationship between Mataraman and Panaragan culture is strengthened by the marriage of Princess Paku Buwono III named Raden Ayu Murtosiah with the grandson of Kiai Ageng Muhammad Besari named Kiai Muhammad Hasan Besari. So it can be concluded that the kinship relationship between the two cultural regions, also affects the language used by the people of Ponorogo in general.

\section{Conclusion}

The language of "bombongan" in Javanese Panaragan in the Ponorogoreyog community, can be used as a benchmark for how warok as ethnic Panaragan figure the reality of the community and the environment in which they are located. The language used, especially the phrase "bombongan" contained in the linguistic data above shows some functions, among others, is as a form of flattery, appreciation, and motivation to others, in this case, is reyog friends, which is the term for the reyog community to have bold character and character, knight and wise. The language is in line with Sapir Whorf's hypothesis that the phrase "bombongan" reflects the mindset of people related to culture. These three aspects interact with each other

\section{References}

[1] Poerwowijoyo, Babad Ponorogo VII. Indonesia: Depdikbudpora, 1985. 
[2] D. D. Steinberg, Nagata, H., and D. P. Aline, Psycholinguistics Language, Mind, and World. London: Longman, 2001.

[3] S. Hardjomartono, Rejog Warok dan Gemblagakan di Ponorogo: Tritunggal yang tidak dapat dipisah-pisahkan. Jakarta: Depertemen Pendidikan dan Kebudayaan, 1962

[4] A. E. Kadarisman, "Hipotesis Sapir-Whorf dan Ungkap Verbal Keagamaan," Linguist. Indones., vol. 26, no. 1, pp. 1-22, 2008.

[5] A. Chaer, Psikolinguistik: Kajian Teoritik. Jakarta: Rineka Cipta, 2009.

[6] G. Fahmi, "Pendidikan Karakter Hipotesisi Sapir Whorf dan Bahasa Intelek di Media Sosial," J. Ta'dib UIN Sunan Ampel Surabaya, 2014.

[7] R. Wiwin, "Teori Sapir-Whorf." .

[8] Soemarto, "Menelusuri Perjalanan Reyog Ponorogo.” Kota reyog, Ponorogo, 2014.

[9] Pemerintah Kabupaten Ponorogo, Pedoman Dasar dalam Pentas Reyog Ponorogo. Ponorogo: Pemerintah Kabupaten Ponorogo, 1993. 